\title{
GDNF Slows Loss of Motoneurons but Not Axonal Degeneration or Premature Death of $\mathrm{pmn} / \mathrm{pmn}$ Mice
}

\author{
Y. Sagot, ${ }^{1}$ S. A. Tan, ${ }^{2}$ J. P. Hammang, ${ }^{3}$ P. Aebischer, ${ }^{2}$ and A. C. Kato ${ }^{1}$ \\ ${ }^{1}$ Department of Pharmacology and Division of Clinical Neuromuscular Research, Geneva University, 1211 Geneva-4, \\ Switzerland, "2Gene Therapy Center and Division of Surgical Research, Lausanne University, 1011 Lausanne, Switzerland, \\ and ${ }^{3}$ Cyto Therapeutics, Inc., Providence, Rhode Island 02906
}

Glial cell line-derived neurotrophic factor (GDNF), a member of the TGF- $\beta$ superfamily, has been shown to be a highly potent neurotrophic factor that enhances survival of various neuronal cell types including motoneurons. To assess its therapeutic potential in treating neurodegenerative diseases such as amyotrophic lateral sclerosis, we treated mutant mice displaying motoneuron degeneration (progressive motor neuropathy; $p m n$ ) with encapsulated GDNF-secreting cells. Effects of GDNF treatment on pmn/pmn mice were compared with previous results obtained with ciliary neurotrophic factor (CNTF) [Sagot Y, Tan SA, Baetge E, Schmalbruch H, Kato AC, Aebischer P (1995) Eur J Neurosci 7:1313-1322].
In contrast to CNTF, GDNF did not increase the lifespan of pmn/pmn mice. However, GDNF significantly reduced the loss of facial motoneurons by $50 \%$, a value similar to what was observed when CNTF was administered to the $p m n / p m n$ mice. Surprisingly, myelinated axon counts revealed that GDNF had no effect on nerve degeneration. Therefore, despite its potential in rescuing motoneuron cell bodies, the inability of GDNF to prevent nerve degeneration in $p m n / p m n$ mice suggests that its usefulness in the treatment of motor neuron diseases may be restricted to cotreatment with other factors that act on the nerve process.

Key words: $\mathrm{pmn} / \mathrm{pmn}$ mice; progressive motor neuronopathy; GDNF; motor neurons; neurodegenerative disease; encapsulated cell line
In the last decade, in vitro and in vivo experiments have supported the view that neurotrophic factors may be used for the treatment of neurodegenerative diseases such as amyotrophic lateral sclerosis (ALS) or spinal muscular atrophy (SMA) (Hefti, 1994; Lindsay et al., 1994). These results have formed the basis for the initiation of clinical trials using systemic and intrathecal delivery of neurotrophic factors in ALS patients (Barinaga, 1994). Among the possible candidates is a new neurotrophic factor, glial cell linederived neurotrophic factor (GDNF). Initially thought to be specific for dopaminergic neurons (Lin et al., 1993, 1994), with protective effects against various chemical insults such as 6-hydroxydopamine (Kearns and Gash, 1995) and 1-methyl-4phenyl-1,2,3,6-tetrahydropyridine (Tomac et al., 1995), GDNF has also been described as a very potent neurotrophic factor for developing motoneurons (Henderson et al., 1994; Zurn et al., 1994; Oppenheim et al., 1995) as well as for adult motoneurons (Li et al., 1995; Yan et al., 1995). The GDNF mRNA distribution (Henderson et al., 1994; Trupp et al., 1995) confirms that GDNF is widely distributed in both the periphery and the CNS, suggesting that it could be involved in trophic responses of motoneurons. Furthermore, in vivo experiments have shown that GDNF can prevent motoneuron cell death after axotomy or ventral root avulsion (Henderson et al., 1994; Zurn et al., 1994; Li et al., 1995;

Received Dec. 4, 1995; revised Jan. 16, 1996; accepted Jan. 24, 1996.

This work was supported by the Association Française contre les Myopathies (France), CytoTherapeutics Inc., and the Swiss National Science Foundation. We thank Dr. J. C. Martinou for reading this manuscript and B. King, V. Padrun, and L. Schnell for their excellent technical assistance. We thank Synergen Inc., Boulder, CO for providing us with the GDNF antibody, and we are grateful to Dr. R. Vejsada for his valuable discussion and reading of this manuscript.

Correspondence should be addressed to Dr. Yves Sagot, Department Pharmacologie, Centre Médical Universitaire, 1 avenue Champel, 1211 Geneva 4, Switzerland.

Copyright (C) 1996 Society for Neuroscience $0270-6474 / 96 / 162335-07 \$ 05.00 / 0$
Oppenheim et al., 1995) and that GDNF mRNA increases shortly after sciatic nerve transection (Trupp et al., 1995). Therefore, these results would suggest a possible role for GDNF in treating motoneuron diseases.

Using an animal model of motor neuronopathy ( $p m n$ ), we determined whether GDNF could slow down or prevent the disease progression. pmn/pmn mice develop weakness in the hindlimbs during the third week of life and die at $\sim 6$ weeks of age (Schmalbruch et al., 1991). Motor nerve profiles demonstrate demyelinization (Schmalbruch et al., 1991) and a degeneration of $30 \%$ of the facial nucleus motoneurons (Sendtner et al., 1992). To continuously release GDNF in $\mathrm{pmn} / \mathrm{pmn}$ animals, we have used a technique that involves the encapsulation of neurotrophic factor-secreting cells in a polymer envelope (Aebischer et al., 1991). As described previously, encapsulation prevents the uncontrolled proliferation of the transplanted cells and the immune rejection of the host (Sagen et al., 1993; Aebischer et al., 1994). pmn/pmn mice have been subcutaneously implanted with two or four capsules at the onset of the disease. A study of the lifespan and histological analyses of the facial motoneurons and phrenic and facial nerves were performed to determine the efficacy of the GDNF treatment.

\section{MATERIALS AND METHODS}

Genetically modified cell line

The rat GDNF vector construction was prepared as described by Zurn et al. (1994). Transfection of baby hamstcr kidncy (BIIK) fibroblasts with this vector was performed using standard calcium phosphate precipitation (Chu and Sharp, 1981; Searle et al., 1985). The transfected BHK cells were then exposed to methotrexate selection for 8 weeks before being assayed for GDNF activity (Zurn et al., 1994). 


\section{Fncapsulation}

Transfected BHK cells were encapsulated in 1-cm-long polypropylene fibres (outer diameter, $550 \mu \mathrm{m}$; inner diameter, $350 \mu \mathrm{m}$; internal volume, $1 \mu \mathrm{l}$ ) at a concentration of $50 \times 10^{3}$ cells $/ \mu \mathrm{l}$ (Zurn et al., 1994). The capsules were kept in an incubator at $37^{\circ} \mathrm{C}$ and $6 \% \mathrm{CO}_{2}$ until use.

\section{Pre- and Post-implantation analyses of the capsules}

Capsules were removed from the mice before perfusion and either tested for biological activity as described below or fixed in $4 \%$ paraformaldehyde in PBS, sectioned, and then stained with cresyl violet to assess cell viability.

Capsules were tested in vitro for biological activity in cultures of ventral spinal cord from E14 embryonic rat (Hayes et al., 1991). Briefly, the ventral part of the spinal cord was dissected from fetal E14 rats. Cells (2 $\times 10^{5}$ ) were seeded onto $13 \mathrm{~mm}$ wells (Costar 48-well tissue-culture clusters; Cambridge, MA) that were treated with polyornithine and grown in $300 \mu \mathrm{l}$ of MEM medium containing $10 \%$ decomplemented horse serum. Capsules or recombinant human GDNF (RhGDNF; Genentech, San Francisco, CA) had been added 2-3 hr after plating. Medium was changed on the third day and RhGDNF added de novo to the control cultures. The choline acetyltransferase (ChAT) activity of the cultures was tested $6 \mathrm{~d}$ after culture (Martinou et al., 1992). Results were submitted to an unpaired Student's $t$ test.

\section{Surgery and postsurgery care}

$p m n$ breeder mice were obtained from the laboratory of Dr. J. L. Guenet (Institut Pasteur, Paris, France); the litters (usually 6-8 animals) contained statistically $25 \%$ pmn/pmn homozygotes.

To determine which mice were $p m n / p m n$, animals were examined for grasp activity of the hindlimbs (Sagot et al., 1995a). pmn/pmn mice were implanted at the onset of the disease (between 15 and $18 \mathrm{~d}$ of age). Mice were anesthetized, and capsules were implanted subcutaneously in the back through a small incision in the skin (Sagot et al., 1995a). In some experiments, the dura was opened through a small incision between vertebrae T11 and T12. The wound was closed with metal clips (Clay Adams, NJ), and mice were kept at $35^{\circ} \mathrm{C}$ until they recovered from the anesthesia. They were then returned to their mother.

The mice were divided into three groups as follows.

Group 1: Untreated $\mathrm{pmn} / \mathrm{pmn}$ mice. Two pmn/pmn mice were added to the $22 \mathrm{pmn}$ homozygotes previously studied (Sagot et al., 1995a) for lifespan determination and for histological studies.

Group 2: In addition to the $12 \mathrm{pmn} / \mathrm{pmn}$ mice implanted with capsules loaded with native BHK cells (2 capsules/animal), 4 pmn/pmn mice received BHK cells transfected with a GDNF antisense vector (RHK-AS-GDNF).

Group 3: pmn/pmn mice implanted with capsules loaded with GDNFsecreting $B H K$ cells. In this group, four subgroups were used. First, mice received two GDNF capsules $(n-7)$. Second, pmn/pmn mice were implanted with two GDNF capsules $(n=15)$ and, concomitantly, the dura was opened. Third, $p m n / p m n$ mice $(n=4)$ received four GDNF capsules without opening the dura and, finally, pmn/pmn mice $(n=7)$ received four GDNF capsules with the dura opened.

Lifespan results were submitted to a Kaplan-Meier test (SPSS for
Windows version 5.0; equality of survival distribution); the $p$ value of $\log$ Rank (Mantel-Cox) is reported. In some cases, the $p$ value of the Breslow test is also included.

To determine whether GDNF could have deleterious effects, normal mice were also implanted with two or four GDNF-secreting capsules ( 8 animals). Histological analyses of untreated normal mice were also performed. Control animals were perfused at different ages ranging from 36 to $91 \mathrm{~d}$ of age.

\section{Dot-blot experiments}

Ten nanograms of Rh-GDNF (Genentech) were spotted onto circular (diameter $8 \mathrm{~mm}$ ) Hybond-N membranes (Amersham, Arlington Heights, IL) and kept at room temperature for 5 min. Membranes were then blocked with 5\% skim milk in TBS for $1 \mathrm{hr}$ at room temperature. After being rinsed three times with TBS, membranes were incubated overnight at $4^{\circ} \mathrm{C}$ with 1:20 diluted sera collected from implanted or nonimplanted mice. After three washes in TBS, the secondary antibody (peroxidaseconjugated rabbit anti-mousc immunoglobulins, Dakopatts, Glostrup, Denmark) was added at 1:1000 dilution for $2 \mathrm{hr}$ at room temperature. After four washes in TBS, the peroxidase activity of the secondary antibody was detected using $3,3^{\prime}$-diaminobenzidine tetrahydrochloride as substrate. In control experiments, the sera were replaced by a polyclonal antibody directed against hGDNF (gift from Synergen, Boulder, CO), previously described by Lin et al. (1993), diluted at 1:2000 and detected with peroxidase-conjugated goat anti-rabbit immunoglobulins (Dakopatts) at 1:1000.

\section{Histological procedures}

Facial nucleus. Mice werc processed as described previously (Sagot ct al., 1995a). Motoncurons of the facial nucleus were counted using a Polyvar microscope at a magnification of $100 \times$. For each animal, the number of facial motoncurons is the mean of the values from both sides. No correction for split nuclei was done. Results were submitted to an unpaired Student's $t$ test.

Phrenic and facial nerves. Nerves were processed as described previ ously (Sagot et al., 1995a). Myelinated axons of the phrenic nerve were counted at a magnification of $630 \times$ using a Zeiss IM 35 microscope. Facial and phrenic nerves were processed in the same way but the facial nerves were photographed and myelinated axons were counted on $18 \times$ $24 \mathrm{~cm}$ paper print. Results were submitted to an unpaired Student's $t$ test.

\section{RESULTS}

\section{BHK-GDNF capsules did not improve survival of pmn/pmn mice}

The goal of our study was to determine whether GDNF had any effect on the lifespan of the $p m n / p m n$ mice. Therefore, capsules containing GDNF-secreting cells were implanted at the onset of the disease (approximately P15-P18). The average lifespan of animals implanted with GDNF-secreting capsules was $47 \mathrm{~d}$, which is not statistically greater than those treated with capsules containing BHK control cells (BHK control capsules) ( $p$

Table I. Effect of GDNF-secreting capsules on $p m n$ disease parameters

\begin{tabular}{lllccc} 
Treatment & Lifespan (days) & Facial motoncurons & Facial nerve & Phrenic nerve \\
\hline None & $43 \pm 1(n=24)$ & $2160 \pm 51$ & $(n=7)$ & $2096 \pm 132^{* *}(n=3)$ & $114 \pm 7^{* * *}(n=12)$ \\
BHK & $44 \pm 3(n=12)$ & $2187 \pm 88 \quad(n=8)$ & n.d. & $111 \pm 6^{* * *}(n=8)$ \\
BHK-AS-GDNF & $41 \pm 3(n=5)$ & $2087 \pm 111 \quad(n=3)$ & n.d. & n.d. \\
BHK-GDNF 2 caps w/o dura opened & $47 \pm 3(n=7)$ & $2465 \pm 109^{*}(n=5)$ & n.d. & n.d. \\
BHK-GDNF 2 caps dura opencd & $47 \pm 3(n=15)$ & $2607 \pm 42^{* * *}(n=9)$ & $2187 \pm 87^{*}(n=4)$ & $118 \pm 9^{* * *}(n=8)$ \\
BHK-GDNF 4 caps w/o dura opened & $47 \pm 4(n=4)$ & $2414 \pm 37^{*}(n=3)$ & n.d. & n.d. & n.d. \\
BHK-GDNF 4 caps dura opened & $41 \pm 2(n=7)$ & $2518 \pm 79^{* *}(n=3)$ & $(n=3)$ & $262 \pm 8 \quad(n=8)$
\end{tabular}

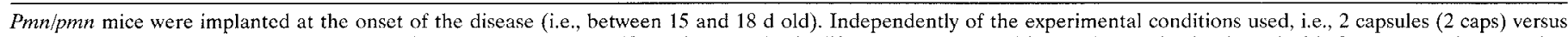

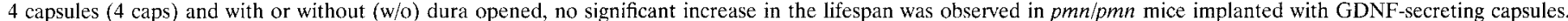

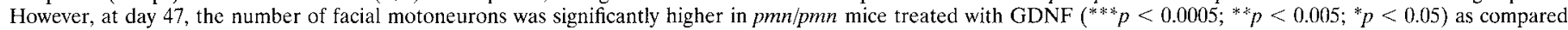

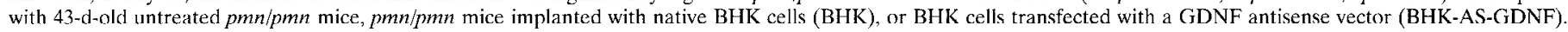

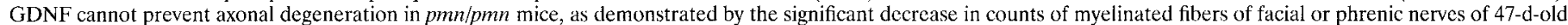
pmn/pmn mice as compared with normal animals $\left({ }^{* * *} p<0.0001\right.$; $\left.{ }^{*} p<0.01\right)$. n.d., Not determined. 
$<0.5)$, BHK cells transformed with the GDNF antisense vector (BHK-AS-GDNF capsules) $(p<0.2)$ or without implants $(p<$ 0.09 ) (Table 1).

It is generally accepted that neurotrophic factors would be more accessible to CNS neurons if they were delivered in the vicinity of their cell bodies rather than in peripheral targets. Because it is impossible to intrathecally implant capsules in pmn/ pmn mice because of their small size, we attempted to increase the accessibility of GDNF to the spinal motoneurons by opening the dura in another group of $\mathrm{pmn} / \mathrm{pmn}$ mice. No difference in lifespan was observed between the two GDNF-treated groups (Table 1). Even when these two groups were pooled, there was no significant difference compared with nonimplanted $p m n / p m n$ mice $(p<$ 0.059 for Log Rank and $p<0.12$ for Breslow) or BHK-implanted mice $(p<0.7)$.

To exclude the possibility that $\mathrm{pmn} / \mathrm{pmn}$-treated mice eventually died from an insufficient supply of GDNF, we implanted two other groups of mice with four GDNF-secreting capsules instead of two. No significant improvement in the lifespan was observed with four GDNF-secreting capsules compared with two capsules $(p<0.4)$. Finally, when we compared these results with our previously described data obtained with CNTF-treated pmn/pmn mice (Sagot et al., 1995a), we found that the lifespan of GDNFimplanted mice was significantly shorter than that observed in CNTF-treated mice $(47.3 \pm 2.7$ vs $58.8 \pm 1 ; p<0.0014$ for $\log$ Rank and $p<0.0001$ for Breslow).

\section{Effect of GDNF-secreting capsules on ventral spinal cord cultures}

It was of interest to determine whether polymer-encapsulated transfected cells still secrete GDNF after being implanted several weeks in animals. We therefore tested the effect of GDNFreleasing capsules on ChAT activity of embryonic rat ventral spinal cord cultures before and after implantation (Fig. 1). No difference in ChAT activity was detected in cultures treated with postimplanted capsules at $10 \mathrm{~d}, 30$, or $90 \mathrm{~d}(n=2$; data not shown), thus demonstrating the stability of the expression of GDNF. The ChAT activity measured from postimplanted capsules is equivalent to $10-20 \mathrm{ng} / \mathrm{ml} \mathrm{RhGDNF}$ and is significantly higher than in freshly prepared capsules $(p<0.001$; Fig. 1 and inset). This increase in bioactivity is probably attributable to a proliferation of the BHK-GDNF cells inside the polymer capsule until they fill the inside of the capsule. In contrast, BHK control or BHK-AS-GDNF capsules did not increase the ChAT activity in the cultures (Fig. 1). No difference in ChAT activity was found between pre- and postimplanted BHK control capsules.

\section{Do implanted mice develop antibodies against GDNF?}

To rule out the possibility that neutralizing antibodies had been generated against GDNF delivered by the capsules, we performed immunoblotting experiments using sera collected from $\mathrm{pmn} / \mathrm{pmn}$ $(n=7)$ and control mice $(n=5)$ implanted with two to four GDNF capsules or with sera from nonimplanted control mice $(n=2)$. Using a dilution of 1:20, none of the sera tested showed immunoreactivity against $10 \mathrm{ng}$ of pure RhGDNF. In contrast, a control antibody against hGDNF diluted at 1:2000 displayed a strong immunoreactive reaction with even $1 \mathrm{ng}$ of pure RhGDNF.

\section{GDNF-secreting capsules slow down the loss of motoneurons but do not prevent the degeneration of myelinated fibers in $\mathrm{pmn} / \mathrm{pmn}$ animals}

It was of interest to evaluate whether the absence of an effect on the lifespan of $p m n / p m n$ mice correlated with the absence of an

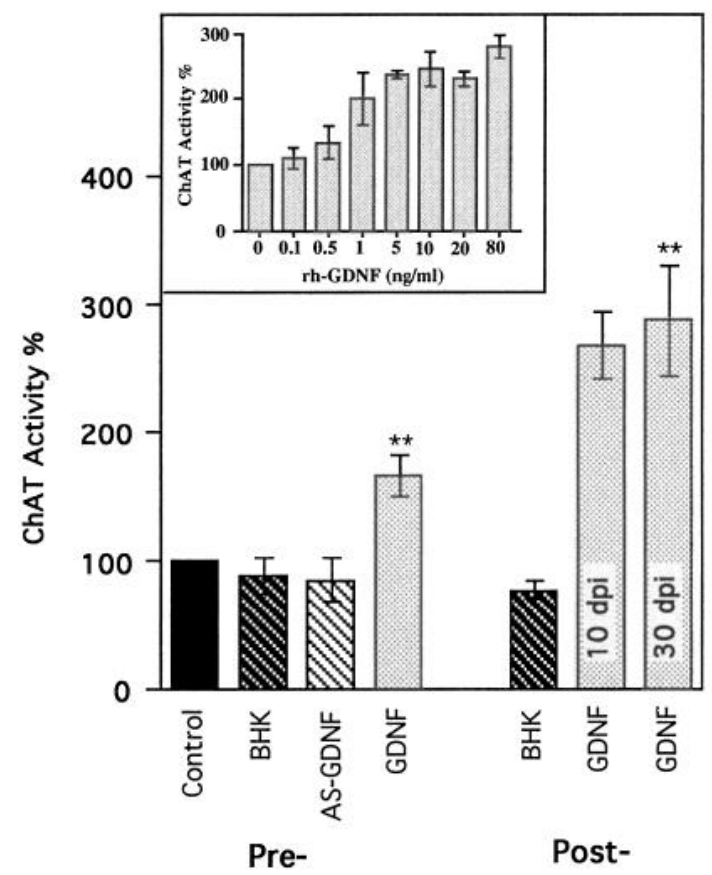

Implantation

Figure 1. Effect of BHK-GDNF capsules on ChAT activity in ventral spinal cord cultures from 14-d-old embryonic rats. ChAT activity was expressed as a percentage of values in the control wells, which contained neither GDNF nor capsules. For preimplantation analysis, 16 control capsules loaded with untransformed BHK cells $(B H K), 5$ capsules loaded with BHK cells transfected with a GDNF-antisense vector $(A S-G D N F)$, and 18 capsules loaded with BHK cells transfected with the GDNF-sense vector $(G D N F)$ were tested within $48 \mathrm{hr}$ after cell encapsulation. For postimplantation analysis, 6 BHK capsules and 12 GDNF capsules were tested at $30 \mathrm{~d}$ postimplantation ( $\mathrm{dpi}$ ). In addition, $2 \mathrm{GDNF}$ capsules were tested $10 \mathrm{~d}$ postimplantation. Pre- and postimplanted GDNF capsules significantly increased the ChAT activity compared with BHK capsules $\left({ }^{* *} p<0.001\right.$ for both). However, postimplanted GDNF capsules were more efficient than preimplanted ones $\left({ }^{*} p<0.01\right)$. A dose-response curve was obtained with rhGDNF (inset). Values represent means \pm SEM of ChAT activity detected in at least three experiments of two to three wells.

effect on motoneuron survival and/or myelinated fibers. As described previously (Sendtner et al., 1992; Sagot et al., 1995a), the facial nucleus of $\mathrm{pmn} / \mathrm{pmn}$ mice at an advanced stage of the disease (i.e., 42 d) contained $30 \%$ fewer motoneurons than control animals. Counts of facial motoneurons performed in 40- to 43-d-old mice that had been implanted with BHK control capsules or BHK-AS-GDNF capsules were not different from the nonoperated pmn/pmn mice (Table 1). In contrast, 47-d-old pmn homozygotes that received GDNF-secreting capsules contained significantly more motoneurons (Table 1 ) than untreated $\mathrm{pmn} / \mathrm{pmn}$ mice, and the most significant effect was observed when the mice were implanted with two GDNF-secreting capsules with the dura open ( $p<0.0005$; Table 1, Figs. 2, 3).

To explain the discrepancy between prevention of motoneuron loss and lifespan in pmn/pmn animals, we examined myelinated axon profiles in cross-sections of facial nerve. In 47-d-old pmn/ pmn mice treated with GDNF-releasing capsules, the number of myelinated axons in the facial nerve was the same as in 42-d-old untreated $\mathrm{pmn} / \mathrm{pmn}$ mice and was significantly smaller than in normal mice of matching age $(p<0.01)$ (Table 1, Figs. 2, 3).

Numbers of myelinated fibers in the phrenic nerve that innervate the diaphragm have been reported to be severely affected in 
A. Facial Nucleus

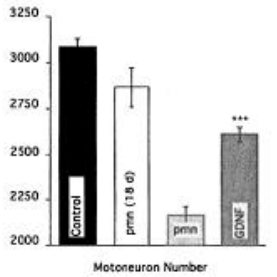

B. Facial Nerve

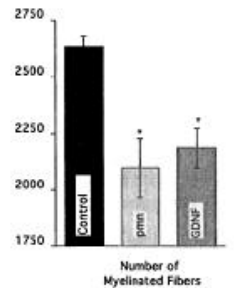

C. Phrenic Nerve

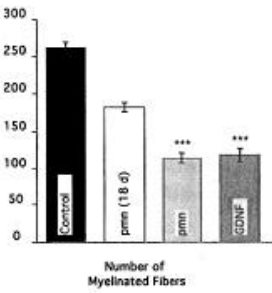

Figure 2. A, Effect of GDNF capsules on the number of facial motoneurons $\pm \mathrm{SEM}$ in $\mathrm{pmn} / \mathrm{pmn}$ mice. At day 47, GDNF-treated $\mathrm{pmn} / \mathrm{pmn}$ mice $(n=9)$ have significantly more motoneurons in the facial nucleus than untreated $\mathrm{pmn} / \mathrm{pmn}$ mice $(n=7)\left({ }^{* * *} p<0.0005\right)$. However, this rescue effect is only partial because 18 -d-old $\mathrm{pmn} / \mathrm{pmn}$ mice $(n=4)$ have more motoneurons $(p<0.05)$ than GDNF-treated $p m n / p m n$ animals. $B, C$ Effect of GDNF capsules on the number of myelinated profiles of facial nerves $(B)$ and phrenic nerves $(C) \pm \mathrm{SEM}$ in $\mathrm{pmn} / \mathrm{pmn}$ mice. For both nerves studied, $p m n / p m n$ mice implanted with GDNF-secreting capsules ( $n=4$ for facial nerves, $n=8$ for phrenic nerves) did not have more myelinated profiles than untreated $\mathrm{pmn} / \mathrm{pmn}$ mice $(n=3$ for facial nerves, $n=12$ for phrenic nerves). This loss of myelinated fibers is significant compared with control animals ( ${ }^{*} p<0.01, n=3$ for facial nerves; *** $p<$ $0.0001, n=8$ for phrenic nerves) or with 18 -d-old $p m n / p m n$ mice $(p<$ $0.0001, n=4$ for phrenic nerve).

pmn/pmn mice (Schmalbruch et al., 1991). After implantation with GDNF-secreting capsules, the phrenic nerve did not display more myelinated axons as compared with untreated pmn/pmn mice (Table 1, Figs. 2, 3). This represents more than a 55\% loss of myelinated axons in the phrenic compared with control animals $(p<0.0001)$.

\section{DISCUSSION}

To study the potential of GDNF for treating neurodegenerative diseases, we have used the pmn mouse mutant as a model of a "dying back" motoneuronopathy (Schmalbruch et al., 1991). The pmn mutation initially affects the axons, and then the cell body. The onset of the disease appears during the third postnatal week, with muscle wasting in the hindlimb and pelvic regions, and the animals die around the seventh week of life (Schmalbruch et al., 1991). Histological and electrophysiological (P. Kennel, personal communication) studies showed that the disease specifically affects myelinated motor fibers, including those of the phrenic and facial nerves (Schmalbruch et al., 1991). Counts of the facial motoneurons revealed that at the late stage of the disease, pmn homozygotes displayed a $30 \%$ reduction in facial motoneurons (Sendtner et al., 1992; Sagot et al., 1995a). Therefore, the pmn mutation may be considered to be a possible genetic model for human motoneuronopathies and a suitable system for studying neurotrophic factor potential.

\section{GDNF cannot prevent disease progression in pmn/pmn mice}

By implanting polymer-encapsulated, GDNF-secreting cell lines, GDNF was permanently administrated to the animals without inducing side effects such as body weight loss. Despite this continuous delivery, GDNF could not slow down the disease progression of the mice. The in vitro bioassay on spinal cord cultures ruled out the possibility that the capsules were not secreting GDNF at the time when the animals died. Interestingly, we found that GDNF-capsules were acting on ChAT activity at an equivalent of 10-20 ng/ml RhGDNF, a value higher than that observed with CNTF capsules (i.e., 5-10 ng/ml RhCNTF). Therefore, this indicates that these GDNF capsules were secreting twofold more neurotrophic factor bioactivity than CNTF capsules (Sagot et al., 1995a). Nevertheless, GDNF had no effect on the lifespan of diseased mice; meanwhile, when pmn/pmn mice had been implanted with CNTF-releasing capsules, there was a $40 \%$ increase in the lifespan (Sagot et al., 1995a). Because we did not observe any difference between the groups with two or four capsules, it does not appear that the absence of effect was attributable to an insufficient supply of GDNF.

There is additional evidence to support the argument that the GDNF supply is not limiting. First, GDNF has been reported to be a highly efficient neurotrophic factor even at very low concentrations in culture (Henderson et al., 1994) and to be more efficient in preventing axotomy-induced cell death in neonatal rodents than CNTF (Henderson et al., 1994; Yan et al., 1995). Second, previous experiments performed with GDNF-secreting capsules have shown that GDNF is secreted in high enough quantities to prevent axotomy-induced cell death in neonatal rodents (Zurn et al., 1994) and to protect the viability and tyrosine hydroxylase immunoreactivity of the substantia nigra pars compacta neurons after a medial forebrain bundle axotomy (J. Tseng and P. Aebischer, unpublished observations). In our experiments, counts of motoneurons in the facial nucleus of diseased animals revealed that GDNF rescued $50 \%$ of them from death, which is the same proportion as in CNTF-treated pmn/pmn mice (Sendtner et al., 1992; Sagot et al., 1995a). This latter observation strongly suggests that GDNF is secreted in a sufficient quantity to diffuse from the capsule implantation site (i.e., under the skin in the back) to the facial nucleus or to the peripheral motor nerves where it can be retrogradely transported by motoneuron axons (Yan et al., 1995). Finally, because there was no immunoreactivity in sera of the mice, it seems unlikely that GDNF has been neutralized because of antibody production. Therefore, the absence of a GDNF effect on the lifespan of $\mathrm{pmn} / \mathrm{pmn}$ mice does not seem to be attributable to either an inadequate quantity or diffusion of the factor but rather to a genuine inability of GDNF to affect the disease progression.

\section{Differential effect of GDNF on motoneuron survival and nerve degeneration}

Our results show that GDNF had a significant effect on motoneuron survival without affecting the lifespan of $\mathrm{pmn} / \mathrm{pmn}$ mice. The absence of GDNF effect on nerve degeneration may explain the lack of efficacy on pmn/pmn survival. Because it has already been shown that CNTF delivery reduced the loss of myelinated fibers of the phrenic nerve by $40 \%$ (Sendtner et al., 1992; Sagot et al., 1995a), we concluded that GDNF was acting on motoneuron soma maintenance rather than on neurite stability or regrowth. This result may be considered surprising because it has been reported that GDNF can promote neurite outgrowth in vitro or in vivo (Ebendal et al., 1995; Hudson et al., 1995; Trupp et al., 1995; Zurn et al., 1995). Nevertheless, in contrast to other experiments dealing with neurons from normal rodents, we have examined the effect of GDNF in a mutant mouse in which nerve integrity is affected. Therefore, it seems that in contrast to CNTF, GDNF cannot slow down the nerve degeneration in this animal model characterized by axon impairment. To determine whether this differential action of GDNF is restricted to the pmn disease, it would be interesting to test GDNF on other mice mutants with neurodegenerative disorders such as wobbler or motor neuron degeneration (mnd). 

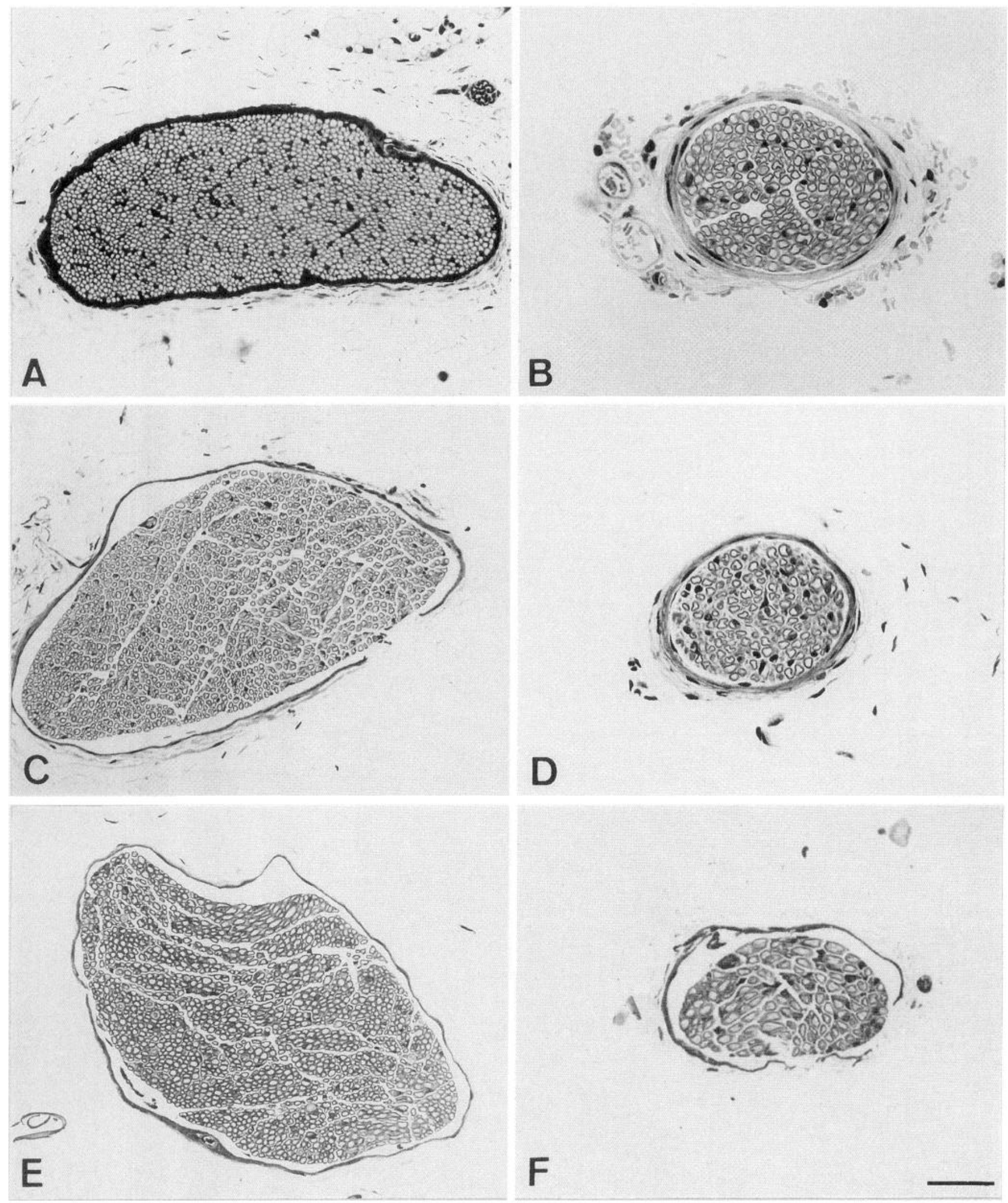

Figure 3. Micrographs of cross-sections of facial nerves $(A, C, E)$ and phrenic nerves $(B, D, F)$ from 42 -d-old mice. $A$ and $B$ are from a normal mouse, $C$ and $D$ are from an untreated pmn/pmn mouse, and $E$ and $F$ are from a pmn/pmn mouse implanted with GDNF-secreting capsules. In nerves from untreated pmn/pmn mice and GDNF-treated pmn/pmn mice, note the reduced number of fibers and loss of nerve compactness. Scale bars: $A, C$, $E$, 100 $\mu \mathrm{m} ; B, D, E, 75 \mu \mathrm{m}$. 


\section{A common pathway between Bcl-2 and GDNF?}

A discrepancy between the preservation of the cell soma and nerve integrity have already been observed in $\mathrm{pmn} / \mathrm{pmn}$ mice overexpressing Bcl-2 (Sagot et al., 1995b). In these mice, Bcl-2 overexpression prevented virtually all of the motoneuron loss without affecting the axonal degeneration. This similarity between the effect of GDNF and $\mathrm{Bcl}-2$ on $\mathrm{pmn} / \mathrm{pmn}$ mice suggests that they may share a common intracellular pathway. Such a possibility is supported by the recent findings of Prehn et al. (1994), who showed that TGF- $\beta$, which belongs to the same family as GDNF, may upregulate Bcl-2 transcription. Interestingly, it has been shown that the mode of action of CNTF is independent of Bcl-2 expression (Allsopp et al., 1993, 1995). Therefore, if GDNF is acting through a Bcl-2 pathway, it might explain the difference between GDNF versus CNTF effects on pmn/pmn mice.

\section{Potential of GDNF in treatment of neurodegenerative diseases of the motoneuron}

To date, studies on the mechanism of action of GDNF have primarily focused on the rescue of motoneuron cell bodies, and there are no reports on its role in axonal sprouting, synapse stabilization, or direct effects on muscle, as have been reported for CNTF (Gurney et al., 1992; Helgren et al., 1994; Kwon and Gurney, 1994). This multiple site of action of neurotrophic factors may be a prerequisite for treating degenerative diseases involving motoneurons. This possibility is reinforced by the demonstration that additive or synergistic effects between neurotrophic factors exist (Wong et al., 1993; Kato and Lindsay, 1994) and may be beneficial in the treatment of a neurodegenerative disease as has been described for the wobbler mousc (Mitsumoto et al., 1994). Recent studies by Zurn et al. (in press) have reported on the synergistic effects of neurotrophic factors in combination with GDNF in cultures of cranial motoneurons. Therefore, GDNF may be a potential therapeutic agent along with other factors such as IGF-1 (for review, see Lewis et al., 1993) and NT-4, which are efficient in producing a sprouting response (Funakoshi et al., 1995).

In conclusion, based on in vitro and in vivo studies, GDNF initially appeared to be a very appealing molecule for treating degenerative diseases associated with the motoneuron. In the present paper, we report that GDNF was unable to act on nerve degeneration, nor was it able to slow down the pmn disease. However, it did display a significant effect on motoneuron cell body survival, suggesting that its therapeutic usefulness may be limited to cotreatment with other agents such as CNTF, IGF-1, or NT-4, which can act directly on the nerve process itself.

\section{REFERENCES}

Aebischer P, Winn SR, Tresco PA, Greene LA, Jaeger CB (1991) Long term cross-species brain transplantation of a polymer encapsulated dopamine-secreting cell line. Exp Neurol 103:269-275.

Aebischer P, Buchser E, Joseph JM, Favre J, de Tribolet N, Lysaght M, Rudnick S, Goddard M (1994) Transplantation in humans of encapsulated xenogeneic cells without immunosuppression: a preliminary report. Transplantation 58:1275-1277.

Allsopp TE, Wyatt S, Paterson HF \& Davies AM (1993) The protooncogene $b c l-2$ can selectively rescue neurotrophic factor-dependent neurons from apoptosis. Cell 73:295-307.

Allsopp TE, Kiselev S, Wyatt S, Davies AM (1995) Role of Bcl-2 in the brain-derived neurotrophic factor survival response. Eur J Neurosci 7:1266-1272.

Barinaga M (1994) Neurotrophic factors enter the clinic. Science 264:772-774.
Chu G, Sharp F (1981) SV40 DNA transfection of cells in suspension: analysis of efficiency of transcription and translation of T-antigen. Gene 13:197-202.

Ebendal T, Tomac A, Hoffer BJ, Olson L (1995) Glial cell line-derived neurotrophic factor stimulates fiber formation and survival in cultured neurons from peripheral autonomic ganglia. J Neurosci Res 40:276-284.

Funakoshi H, Belluardo N, Arenas E, Yamamoto Y, Casabona A, Persson H, Ibanez CF (1995) Muscle-derived neurotrophic-4 as an activitydependent trophic signal for adult motor neurons. Science 268:1495-1499.

Gurney ME, Yamamoto H, Kwon Y (1992) Induction of motor neuron sprouting in vivo by ciliary neurotrophic factor and basic fibroblast growth factor. J Neurosci 12:3241-3247.

Hayes V, Cadelli D, Kato AC (1991) Differential modulation of the cholinergic activity of rat CNS neurons in culture. Dev Brain Res 62:159-168.

Hcfti F (1994) Ncurotrophic factor therapy for nervous system degenerative diseases. J Neurobiol 25:1418-1435.

Helgren ME, Squinto SP, Davis HL, Parry DJ, Boulton TG, Heck CS, Zhu Y, Yancopoulos GD, Lindsay RM, DiStefano PS (1994) Trophic effect of ciliary neurotrophic factor on denervated skeletal muscle. Cell 76:493-504.

Henderson CE, Phillips HS, Pollock RA, Davies AM, Lemeulle C, Armanini M, Simpson LC, Moffet B, Vandlen RA, Koliatsos VE, Rosenthal A (1994) GDNF: a potent survival factor for motoneurons present in peripheral nerve and muscle. Science 266:1062-1064.

Hudson J, Granholm A-C, Gerhardt GA, Henry MA, Hoffman A, Biddle P, Leela NS, MacKerlova L, Lile JD, Collins F, Hoffer BJ (1995) Glial cell line-derived neurotrophic factor augments midbrain dopaminergic circuits in vivo. Brain Res Bull 36:425-432.

Kato AC, Lindsay RM (1994) Overlapping and additive effects of neurotrophins and CNTF on cultured human spinal cord neurons. Exp Neurol 130:196-201.

Kearns CM, Gash DM (1995) GDNF protects nigral dopamine neurons against 6-hydroxydopamine in vivo. Brain Res 672:104-111.

Kwon YW, Gurney ME (1994) Systemic injections of ciliary neurotrophic factor induce sprouting by adult motor neurons. NeuroReport 5:789-792.

Lewis ME, Neff NT, Contreras PC, Stong DB, Oppenheim RW, Grebow PE, Vaught JL (1993) Insulin-like growth factor-I: potential for treatment of motor neuronal disorders. Exp Neurol 124:73-88.

Li L, Wu W, Lin L-FII, Lei M, Oppenheim RW, Houcnou LJ (1995) Rescue of adult mouse motoneurons from injury-induced cell death by glial cell line-derived neurotrophic factor. Proc Natl Acad Sci USA 92:9771-9775.

Lin L-FH, Doherty DH, Lile JD, Bektesh S, Collins F (1993) GDNF: a glial cell line-derived neurotrophic factor for midbrain dopaminergic neurons. Science 260:1130-1132.

Lin L-FH, Zhang TJ, Collins F, Armes LG (1994) Purification and initial characterization of rat B49 glial cell line-derived neurotrophic factor. J Neurochem 63:758-768.

Lindsay RM, Wiegand SJ, Altar CA, DiStefano PS (1994) Neurotrophic factors: from molecule to man. Trends Neurosci 17:182-190.

Martinou J-C, Martinou I, Kato AC (1992) Cholinergic differentiation factor (CDF/LIF) promotes survival of isolated rat embryonic motoneurons in vitro. Neuron 6:737-744.

Mitsumoto H, Ikeda K, Klinkosz B, Cedarbaum JM, Wong V, Lindsay RM (1994) Arrest of motor ncuron disease in wobbler micc cotreated with CNTF and GDNF. Science 265:1107-1110.

Oppenheim RW, Houenou LJ, Johnson JE, Lin L-FH, Li L, Lo AC, Newsome AL, Prevette DM, Wang S (1995) Developing motor neurons rescued from programmed and axotomy-induced cell death by GDNF. Nature 373:344-346.

Prehn JHM, Bindokas VP, Marcuccilli CJ, Krajewski S, Reed JC, Miller RJ (1994) Regulation of neuronal Bcl2 protein expression and calcium homeostasis by transforming growth factor type $\beta$ confers wide-ranging protection on rat hippocampal neurons. Proc Natl Acad Sci USA 91:12599-12603.

Sagen J, Wang H, Tresco PA, Aebischer P (1993) Transplants of immunologically isolated xenogeneic chromaffin cells provide a long-term source of pain reducing neuroactive substances. J Neurosci 13:2415-2423.

Sagot Y, Tan SA, Baetge E, Schmalbruch H, Kato AC, Aebischer P (1995a) Polymer encapsulated cell lines genetically engineered to re- 
lease ciliary ncurotrophic factor can slow down progressive motor neuronopathy in the mouse. Eur J Neurosci 7:1313-1322.

Sagot Y, Dubois-Dauphin M, Tan SA, de Bilbao F, Aebischer P, Martinou J-C, Kato AC (1995b) Bcl-2 overexpression prevents motoneuron cell body loss but not axonal degeneration in a mouse model of a neurodegenerative disease. J Neurosci 15:77'27-7733.

Schmalbruch H, Jensen H-JS, Bjaerg M, Kamieniecka Z, Kurland L (1991) A new mouse mutant with progressive motor neuronopathy. J Neuropathol Exp Neurol 50:192-204.

Searle PF, Stuart GW, Palmiter RD (1985) Building a metalresponsive promoter with synthetic regulatory elements. Mol Cell Biol 5:1480-1489.

Sendtner M, Schmalbruch H, Stöckli KA, Carroll P, Kreutzberg GW, Thoenen H (1992) Ciliary neurotrophic factor prevents degeneration of motor neurons in mouse mutant progressive motor neuronopathy. Nature 358:502-504.

Tomac A, Lindqvist E, Lin L-FH, Ögren SO, Young D, Hoffer BJ, Olson
L (1995) Protection and repair of the nigrostriatal dopaminergic system by GDNF in vivo. Nature 373:335-339.

Trupp M, Rydén M, Jörnvall H, Funakoshi H, Timmusk T, Arenas E, Ibanez CF (1995) Peripheral expression and biological activities of GDNF, a new neurotrophic factor for avian and mammalian peripheral neurons. J Cell Biol 130:137-148.

Wong V, Arriaga R, Ip NY, Lindsay RM (1993) The neurotrophins BDNF, NT-3, and NT-4/5, but not NGF, up-regulate the cholinergic phenotype of developing motor neurons. Eur J Neurosci 5:466-474.

Yan Q, Matheson C, Lopez OT (1995) In vivo neurotrophic effects of GDNF on neonatal and adult facial motor neurons. Nature 373:341-344.

Zurn AD, Baetge EE, Hammang JP, Tan SA, Aebischer P (1994) Glial cell line-derived neurotrophic factor (GDNF), a new neurotrophic factor for motoneurones. NeuroReport 6:113-118.

Zurn AD, Winkel L, Menoud A, Djabali K, Aebischer P (1996) Combined effects of GDNF, BDNF, and CNTF on motoneuron differentiation in vitro. J Neurosci Res, in press. 